\title{
Dysfunctions in Dopamine Systems and ADHD: Evidence from Animals and Modeling
}

\author{
Davide Viggiano, Daniela Vallone ${ }^{1 \S}$ and Adolfo Sadile \\ Laboratory of Neurophysiology, Behaviour and Neural Networks, Department of Experimental \\ Medicine, II University of Naples, Naples, Italy; ${ }^{1}$ Friedrich Miescher Laboratorium \\ Max-Planck Institute für Entwicklungsbiologie, Tuebingen, Germany
}

\section{SUMMARY}

Animal models are useful for characterizing neural substrates of neuropsychiatric disorders. Several models have been proposed for the study of Attention Deficit Hyperactivity Disorder (ADHD). The models can be divided into various groups: (i) genetically derived hyperactivity/ inattention, (ii) animal models showing symptoms after pharmacological intervention, and (iii) those based on spontaneous variations in a random population. Spontaneously hypertensive (SHR) and Naples High Excitability (NHE) rats show behavioral traits featuring the main aspects of ADHD in humans but show different changes in dopamine (DA) systems. In fact, the enzyme tyrosine hydroxylase is hyperexpressed in NHE rats and hypoexpressed in SHR. The DA transporter is hyperexpressed in both lines, although in the SHR, DAT activity is low (reduced DA uptake). The DA levels in the striatum and prefrontal cortex are increased in the juvenile SHR, but are decreased in handled young and non-handled older animals. The mRNA of the D1 DA receptor is upregulated

Reprint requests to: A.G. Sadile, Lab. Neurophysiol., Behav. \& Neural Networks, Dept. Exptl. Med. II Univ. Naples, Costantinopoli 16,80138 , Naples, Italy

e-mail: adolfo.sadile@unina2.it

${ }^{8} \mathrm{D}$. Vallone is in the $\mathrm{PhD}$ program in Neuroscience at II Univ Naples in the prefrontal cortex of SHR and downregulated in NHE. The D2 DA receptors are likely to be hypofunctioning in SHR, although the experimental evidence is not univocal, whereas their mRNA is hyperexpressed in NHE. Thus, in SHR both the mesocortical and mesolimbic DA pathways appear to be involved, whereas in NHE only the mesocortical system. To understand the effects of methylphenidate, the elective ADHD drug treatment in humans, in a dysfunctioning DA system, we realized a simple mathematical model of DA regulation based on experimental data from electrophysiological, cyclic voltammetry, and microdialysis studies. This model allows the estimation of a higher firing frequency of DA neurons in SHR rats and suggests that methylphenidate increases attentive processes by regulating the firing rate of DA neur ons.

\section{KEYWORDS}

ADHD, dopamine system, motor activity, attention, behavior, review, model

\section{INTRODUCTION}

The use of animal models in the study of neuropsychiatric disorders is useful in the 
characterization of neurological substrates of the main features of a given disorder. Moreover, animal models can be necessary for testing new pharmacological treatments and for studying the mechanisms of action of already used drugs. To this aim, an animal model should generally reproduce symptomatic expression of the disease, its treatment responses, and pathophysiology. According to Davids et al. (2003), a model should have (a) face validity, that is display fundamental behavioral deficits found in the neuropsychiatric disease, (b) construct validity, that is to conform a theoretical rationale and (c) predictive validity or an ability to predict unknown aspects of the disease.

Attention Deficit Hyperactivity Disorder (ADHD) has been modeled using different strategies. Several reasons argue for the use of animal models in the study of ADHD.

1. First, the midbrain dopamine (DA) system, which includes the ventral tegmental area (A10, VTA) and the substantia nigra (A9, SN), thought to play a central role in the pathogenesis of ADHD, is relatively similar in different mammals.

2. Second, the molecular targets of methylphenidate, the main pharmacological treatment of ADHD, are highly conserved in rats and humans.

3. Finally, hyperactivity and inattention can be measured in small laboratory animals like rodents. Moreover, ADHD morphofunctional substrates are likely to be the same in rats and humans.

In particular, two main strategies have been adopted: (i) selection of animals based on the similarity of some of their behaviors to the human symptoms, and (ii) lesions thought to reproduce the pathogenesis of the human disease. Solanto (2000) proposed that valid models of clinical ADHD should include the following:

- a deficit in measures of attention and not only hyperactivity;
- an improvement of both cognitive and motor deficits by stimulants and other clinically effective treatments in clinically plausible doses,

- an immediate onset of action and lack of tolerance or sensitization with repeated administration of drugs used to treat ADHD, and

- an effect of therapeutic agents on both DA and norepinephrine (NE) systems.

The various animal models proposed for the study of ADHD can be divided into those displaying genetically derived hyperactivity/inattention, those acquiring these changes after pharmacological intervention, and those based on spontaneous variations in a random population. The models comprise mice, rats, and monkeys (see also Comings, 2001; Davies et al., 2001; Davids et al., 2003).

Most studies on animal models of ADHD focus on changes in the catecholamine (DA, NE) systems, but these may represent only part of the neurobiological changes. As a matter of fact, changes in other systems such as the hippocampus (Sadile, 1993), the hypothalamic-hypophyseal axis (Sadile, 1993; King et al., 2000), the NE system (Russell et al., 2000; see also companion paper by Viggiano et al., 2004 - this issue), cholinergic (Russell et al., 2000; Viggiano et al., 2003b), and serotonin systems (Gainetdinov et al., 1999; Adriani et al., 2003) have been reported in some animal models. In particular, many toxins that give rise to a hyperDArgic behavioral profile (see also Masuo et al., 2004 - this issue) are correlated to peculiar changes in the cerebellar vermis (Ferguson \& Cada, 2003), which have been reported to be present also in human ADHD (Castellanos et al., 1996). In fact these models are grouped overall as models with 'cerebellar stunting' (Ferguson \& Cada, 2003).

The correlation with such changes and the changes in the DA system is unclear and has never 
been studied in detail. These changes, in fact, may arise as independent alterations, or are the result of a common cause or could be directly connected.

Here we review the neurophysiologic and biochemical evidence for an alteration of the DA system in two rat models of ADHD, spontaneously hypertensive rats (SHR) and Naples High Excitability (NHE) rats. Moreover, a unitary view of the effects of methylphenidate in a hypothesized dysfunction of DA system is addressed using a simple mathematical model of the regulation of DA at the synaptic cleft.

\section{SPONTANEOUSLY HYPERTENSIVE AND NAPLES HIGH EXCITABILITY RATS}

The SHR strain was selected for familial hypertension in Japan by Okamoto (1969) in the early 1960s. Interestingly, the selection process also resulted in behavioral hyperactivity, which was subsequently disentangled from hypertension by Hendley and Ohlsson (1991), producing the Wistar-Kyoto (WKY) hypertensive (WKY-HT) and WKY hyperactive (WK-HA) strains.

The SHR rat strain shows increased locomotor activity compared with WKY rats during forced exploration, that is in open field conditions (Tilson et al., 1977; Hendley et al., 1985; Sagvolden et al., 1993) in their own home cage and in simple mazes (Làt maze) (Aspide et al., 1996). This hyperactivity appears to be modulated by environmental factors, as continuous handling can reduce the locomotor activity in SHR below the level of WKY controls (Ferguson \& Cada, 2003). This behavior has received a number of different explanations, such as a loss of habituation in a novel environment, altered emotional reactivity, and delayed aversion, but its relevance has been recently challenged. Recent longitudinal studies by Ferguson et al. al. (2003) show normal locomotor activity in an open field. Nevertheless, the longitudinal design may impair the significance of these findings as perinatal manipulation and behavioral experience normally lead to reduced hyperactivity in novelty situations. Multiple evidence of the alteration of DA and NE (see accompanying paper) systems in SHR has emerged, although many reports show contrasting results (see below).

On the other hand, NHE rats have been selected for their higher exploration in the Lat maze. They do not display hyperactivity in their home cage (Sadile, 1993), whereas novelty induced hyperactivity increases as a function of the complexity of the environment (Sadile et al., 1988, 1993; Viggiano et al., 2002b, 2003b).

\section{SYNTHESIS, CLEARANCE, CONCENTRATION, AND EFFECTS OF DA IN ANIMAL MODELS}

The expression of the tyrosine hydroxylase (TH) gene encoding the rate-limiting enzyme in the synthesis of catecholamines, including DA, is normal in NHE and SHR rats (Fig. 1); the protein,

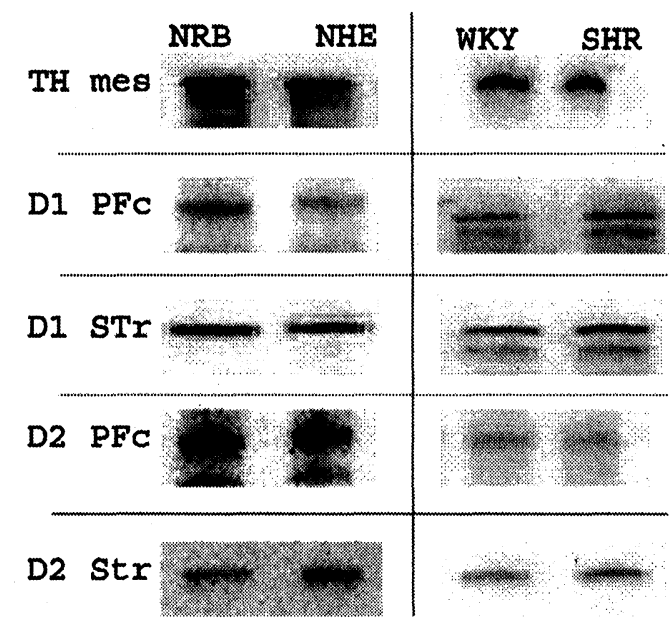

Fig. 1: Distribution of mRNA for tyrosine hydroxylase (TH) in the ventral mesencephalon (mes), and $\mathrm{D} 1 / \mathrm{D} 2$ receptor mRNA in prefrontal cortex $(\mathrm{PFc})$ and striatum (Str) of NHE, NRB, SHR and WKY rats as assessed by RNAase protection assay 
however, is upregulated in NHE and downregulated in SHR in the prefrontal cortex $(\mathrm{PFc})$ (King et al., 2000; Leo et al., 2003), whereas in the striatum it is similar to their respective controls (King et al., 2000), under basal conditions. This difference was detected in young adult NHE rats (Viggiano \& Sadile, 2000, Viggiano et al., 2002a,b; 2003a,b). Interestingly, TH mRNA is down-regulated in the striatum in a bounded postnatal period from P7 through P14 in SHR (Leo et al., 2003). In the ventral mesencephalon, the expression of TH mRNA is normal in both NHE and SHR rats (Fig 1) when compared with their respective controls.

The integral plasmalemmal protein dopamine transporter (DAT) responsible for DA clearance is hyperexpressed in both NHE (Viggiano et al., 2002b, 2003b) and SHR rats (Watanabe et al., 1997), in the PFc, and, at least for SHR animals, in the striatum. In synaptosomal preparations from the striatum, however, the reuptake of DA by the DAT is reduced in SHR compared with controls (Leo et al., 2003). This would suggest that the DAT is hypofunctioning in the SHR. Therefore, in studies involving DA release from slices, the lower reuptake leads to reduced DA release, thus mimicking hypofunctioning DA terminals (Russell, 2003).

As a consequence, less DA is cleared from the synaptic cleft and the tonic level of DA is higher, as showed by microdialysis studies in juvenile SHR animals (Howes et al., 1984; Carboni et al., 2003). In contrast, the levels of DA in the striatum are normal in NHE rats (Carboni et al. personal communication), whereas no data are available about the PFc.

Consistently, depletion of DA by 6-hydroxydopamine lesion of the substantia nigra of SHR decreases the magnitude of adult hypertension (van den Buuse et al., 1985, 1986; Linthorst et al., 1994; de Jong et al., 1995). Interestingly, intensive postnatal handling can reduce the difference between SHR and WKY in terms of the basal levels of DA and locomotor activity (Ferguson \& Cada, 2003; Ferguson et al., 2003), possibly due to a reshaping of the neural networks (Sadile, 1999). Unfortunately, the electrophysiological response of DA neurons in the phasic and tonic mode has not yet been explored in hyperactive models.

The DA receptors also show peculiar changes in these hyperactive animals. The D1 DA receptor is postsynaptic; therefore, its expression level can be related to the effects of DA (Jackson et al., 1994; Missale et al., 1998). D2 DA receptors are both post and presynaptic, therefore related to inhibitory and feedback effects. Strikingly, the pattern of expression of the D1-D2 receptors is very different in SHR and NHE rats. The D1 receptor protein and mRNA are hyperexpressed in SHR (striatum and PFc) ( $\mathrm{Lim}$ et al., 1989; Kirouac \& Ganguly, 1993; Watanabe et al., 1997; Sadile, 1999), whereas in NHE rats D1 mRNA is hypoexpressed in the PFc (Fig. 1) (Viggiano et al., $2002 b)$. The $D 2$ receptors have been reported to be hyper- (see also Fig. 1), hypo-, or normoexpressed (Lim et al., 1989; Watanabe et al., 1989; Kirouac \& Ganguly, 1993; Linthorst et al., 1993; Sadile, 1999; Vaughan et al., 1999; Russell et al., 2000) in the striatum of SHR, whereas their mRNA is hyperexpressed in the striatum of NHE rats, without changes in the PFc (Fig. 1). Some of the conflicting results on the SHR (see also Table 1) may be explainable by different experimental setups or the age of the animals. The high genetic heterogeneity of the WKY strain among different commercial suppliers should also be considered (Samani et al., 1989).

Therefore, the higher DA release in SHR is accompanied by enhanced effects on a postsynaptic site (D1), although whether D1 receptors are normofunctioning in SHR is still being debated. Conversely, in NHE rats, a higher DA release is accompanied by lower postsynaptic effects (D1) and enhanced feedback inhibition (D2).

Finally, the DA branches appear to be differentially involved in SHR and NHE rats. In the 
TABLE I

\begin{tabular}{|c|c|c|}
\hline \multicolumn{3}{|c|}{ SHR } \\
\hline Target & Change & Brain region \\
\hline Locomotor activity & $\begin{array}{l}>\text { (Hellstrand, 1980; Fuller, 1983; Ueno et al., } 2002 \text { 2002; Fujita, 2003) } \\
\text {-(Ferguson, 2003; Yang et al., 2003) } \\
<\text { (Ferguson, 2003) }\end{array}$ & \\
\hline Attention & $<$ (Ueno et al., 2002) & \\
\hline \multirow[t]{2}{*}{ TH } & $<$ (King et al., 2000; Leo et al., 2003) & PFc \\
\hline & -(King et al., 2000) & Striatum \\
\hline DAT & $>$ (Watanabe et al., 1997) & Striatum \\
\hline DAT function (reuptake) & $<$ (Leo et al., 2003; Russell, 2003) & Striatum \\
\hline \multirow[t]{2}{*}{$\mathrm{DA}$} & $\begin{array}{l}\text { Juvenile animals, basal conditions: } \\
>\text { (Howes et al., 2002b, 2003b 1984; Carboni et al., 2003) } \\
\text { older animals or after handling: } \\
<\text { (Linthorst et al., 1991; Sutoo, 1993; Nakamura, 2001; Fujita, 2003) } \\
\text {-(Fuller, 1983; Yu, 1990; Inada, 1992; Ferguson, 2003) }\end{array}$ & Striatum \\
\hline & $>($ Carboni et al., 2003) & PFc \\
\hline DA stimulated release & $<($ van den Buuse et al., 1991; Yousfi-Alaoui, 2001; Russell, 2003) & PFc, striatum \\
\hline D1 R & $\begin{array}{l}>\text { (Lim et al., 1989; Kirouac \& Ganguly, 1993; Watanabe et al., 1997; Sadile, } \\
\text { 1999) } \\
\text {-(Hellstrand, 1980; Watanabe et al., 1989; Linthorst et al., 1993) }\end{array}$ & Striatum \\
\hline D2 R (presynaptic) & $\begin{array}{l}>\text { (Lim et al., 1989; Kirouac \& Ganguly, 1993; Vaughan et al., 1999; } \\
\text { Russell et al., 2000) } \\
<\text { (Sadile, 1999) } \\
\text {-(Watanabe et al., 1989; Linthorst et al., 1993) }\end{array}$ & Striatum \\
\hline Mesolimbic projection & - (King et al., 2000) & \\
\hline Mesocortical projection & $<$ (King et al., 2000) & \\
\hline Hyperactivity after MPH & $\begin{array}{l}-(\text { Yang et al., 2003) } \\
<\text { (Ueno et al., 2002) } \\
\end{array}$ & \\
\hline \multicolumn{3}{|c|}{$\begin{array}{l}\text { NHE rats } \\
\text { see (Viggiano \& Sadile; 2000; Viggiano et al., 2002a,b, 2003a,b) and Fig } 1\end{array}$} \\
\hline \multirow[t]{2}{*}{$\mathrm{TH}$} & $>$ & PFc \\
\hline & - & Striatum \\
\hline DAT & $>$ & PFc \\
\hline $\mathrm{DA}$ & - & Striatum \\
\hline \multirow[t]{2}{*}{ D1 } & $<($ mRNA $)$ & PFc \\
\hline & $-(\mathrm{mRNA})$ & Striatum \\
\hline \multirow[t]{2}{*}{ D2 } & $-($ mRNA $)$ & PFc \\
\hline & $>$ (mRNA) & Striatum \\
\hline Mesolimbic projection & - & \\
\hline Mesocortical projection & $>$ & \\
\hline
\end{tabular}

$<$ : decreased; >: increased; -: unchanged 
former, the mesolimbic branch has received more attention, showing an anterior segmental defect (Sadile, 2000), although the mesocortical one might be involved as well (King et al., 2000). In NHE rats, only the mesocortical branch appears to be involved, being hypertrophic (Viggiano \& Sadile, 2000; Viggiano et al., 2002a,b; 2003a,b). Therefore, different changes in the DA machinery can be correlated to hyperactivity or to different types of hyperactivity. A direct translation of neurobiological changes into behavioral correlates is difficult, however, given our poor understanding of the actual gears of this machinery.

The psychostimulant drug methylphenidate used in the treatment of ADHD has been widely studied in these animal models (Wultz et al., 1990; Sadile, 1999; Aspide et al., 2000; Russell et al., 2000; Andersen et al., 2002; Fox et al., 2002; Carboni et al., 2003; Ferguson \& Cada, 2003; Yang et al., 2003). Som e investigators have postulated that mesencephalic presynaptic D2 receptors in normal animals are more sensitive to low doses of direct agonists (Skirboll et al., 1979; Carlson et al., 1987; Piercey et al., 1996). As a consequence, a biphasic response to methylphenidate results as low doses of DA agonists would reduce tonic spiking and decrease motor behavior (Carlsson, 1975; Strombom, 1975; Doare et al., 1986), whereas high doses are sufficient to activate directly post-synaptic receptors, thereby increasing motor activity. Therapeutic doses of methylphenidate, which are very low, should act to decrease DA-catecholamine transmission (Seeman \& Madras, 1998; Solanto, 1998). Nevertheless, some authors reported that the indirect-acting stimulants methylphenidate (Ruskin et al., 2001) and amphetamine (Piercey et al., 1996) do not have a preferential action on D2 auto-receptors. In fact, the injection of methylphenidate leads to a dose-dependent decrease in the firing rate of DA neurons, which can be reversed by the inhibition of D2 receptors (Ruskin et al., 2001). Moreover, methyl-phenidate also increases the excitability of post-synaptic neurons (Ruskin et al., 2001). In vivo methyl-phenidate increases the release of DA in target regions (Kuczenski \& Segal, 1989; Pehek et al., 1990; Carboni et al., 2003).

In the next session, we will address the effects of methylphenidate using a modeling approach.

\section{MODELING THE REGULATION OF DOPAMINE AT SYNAPTIC SITES AND THE EFFECTS OF METHYLPHENIDATE}

Several models of the DA system have been proposed. Higher level models are mainly based on the experiments by Schultz and collaborators (Schultz et al., 1992) showing that DA neurons increase their firing rate during unexpected rewards (Schultz et al., 1997). Besides, biophysical models of the regulation of DA release have been proposed (Cragg et al., 2001; Schmitz et al., 2001; Schonfuss et al., 2001; Venton et al., 2003; Viggiano et al. 2004), but they do not address the effects on the firing of DA neurons, as discussed below. The latter regulation, in fact, is important when considering changes in the brain of hyper-active animals and the effects of methylphenidate.

In the striatum, the resting levels of extracellular DA are 2 to $6 \mathrm{nM}$ (Huff \& Davies, 2002). This concentration results from the balance between the opposing processes of release and uptake (Wightman, 1988, 1990). The general equation describing this relation is given by (Garris et al., 1994; Wu et al., 2001):

$$
\mathrm{d}[\mathrm{DA}] / \mathrm{dt}=\mathrm{d}[\mathrm{DA}]_{\text {release }} / \mathrm{dt}-\mathrm{d}[\mathrm{DA}]_{\text {uptake }} / \mathrm{dt}
$$

where $d[D A] / d t$ is the rate of change of extracellular DA, $\mathrm{d}[\mathrm{DA}]_{\text {release }} / \mathrm{dt}$ is the release rate, and $\mathrm{d}[\mathrm{DA}]_{\text {uptake }} / \mathrm{dt}$ is the uptake rate by the DA transporter.

The release of DA can be treated as a discrete process, every firing event being associated with 
the release of a constant amount of DA, resulting in an instantaneous increase in [DA]. Therefore, the rate of $\mathrm{DA}$ release is determined by the firing rate $(f)$ of DA neurons. Each spike will release a constant (quantum) amount of DA $\left([\mathrm{DA}]_{\mathrm{p}}\right)$. Thus:

$$
\mathrm{d}[\mathrm{DA}]_{\text {release }} / \mathrm{dt}=[\mathrm{DA}]_{\mathrm{p}} * f
$$

$[D A]_{p}$ represents the concentration of DA after a single spike.

The uptake of DA can be treated as a continuous process following Michaelis-Menten kinetics. The reaction scheme can be represented with

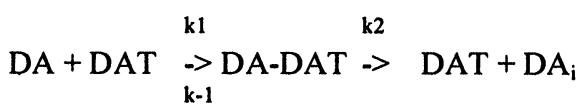

where $\mathrm{DA}_{\mathrm{i}}$ represents the concentration of intracellular DA. The above reaction can also follow the opposite direction, with DAT acting by extrusion of DA into the extracellular space (Falkenburger et al., 2001). This might take place on DA neuron dendrites, where a special dendrodendritic communication has been shown.

Using the Michaelis-Menten law in a quasisteady-state approximation, we get:

$$
\mathrm{d}[\mathrm{DA}]_{\mathrm{i}} / \mathrm{dt}=\mathrm{V} \max *[\mathrm{DA}] /([\mathrm{DA}]+\mathrm{Km})
$$

where $\mathrm{Km}$ is equal to:

$$
\mathrm{Km}=\left(\mathrm{k}_{-1}+\mathrm{k}_{2}\right) / \mathrm{k}_{1}
$$

and is related to the affinity of DA for the transporter and to its turnover rate, whereas Vmax is a constant equal to:

$$
\mathrm{V}_{\max }=\mathrm{k}_{2}[\mathrm{DAT}]_{\mathrm{TOT}}
$$

reflecting the number of uptake or transporters sites.

Here $[\mathrm{DAT}]_{\text {TOT }}$ represents the total amount of enzyme and is equal to:

$$
[\mathrm{DAT}]_{\mathrm{TOT}}=[\mathrm{DAT}]+[\mathrm{DA}-\mathrm{DAT}] \text {. }
$$

Because the rate of formation of $\mathrm{DA}_{i}$ is equal to the rate of DA internalization, we can write:
$\mathrm{d}[\mathrm{DA}] / \mathrm{dt}=-\mathrm{d}[\mathrm{DA}]_{\mathrm{i}} / \mathrm{dt}=-\mathrm{Vmax} *[\mathrm{DA}] /([\mathrm{DA}]+\mathrm{Km})(4)$

Recent data suggest that the DAT also elicits ion-channel-like currents, increasing the firing rate of DA neurons in vitro after blockade of D1, D2, and adrenergic receptors (Ingram et al., 2002). The relevance of such a system in vivo is still being debated. Moreover, the DAT can be regulated by D2 receptors (Wu et al., 2002). In fact, the inhibition of $\mathrm{D} 2$ receptors decreases the rate of clearance of DA, but this effect is not evident after DAT blockade. It should be noted that the clearance of DA also depends on diffusion, as shown by voltammetry studies in vivo after DAT blockade. This mechanism of clearance is dependent on the initial concentration of DA/D2 receptors and the firing rate, and is important just after the release of DA, when DA reaches concentrations in the micromolar range in the synapse for very short times. The diffusion of DA has been previously modeled (see e.g. Garris et al., 1997; Cragg et al., 2001; Schonfuss et al., 2001; Venton et al., 2003) and must be taken into account if considering DA at the single synapse on a very short time scale (after 40 microseconds) more than $96 \%$ of DA has diffused out of the synaptic site (Garris et al., 1994). However, here we will focus on a greater space and longer timescales. Finally, some authors (Mercuri et al., 1997) suggested that another important mechanism of DA clearance is represented by monoamine oxidase (MAO-a and MAO-b).

As here we were mainly interested in the effects of methylphenidate, we did not include diffusion, MAO, or DAT-linked channels in the present simulation. The rate of extracellular DA change during activity can be described by combining Eqs. (2) and (4) (see also Garris et al., 1994; Wu et al., 2001):

$\mathrm{d}[\mathrm{DA}] / \mathrm{dt}=\left([\mathrm{DA}]_{\mathrm{p}} * f\right)-(\mathrm{Vmax} *[\mathrm{DA}] /([\mathrm{DA}]+\mathrm{Km}))$ 
Estimations for $[\mathrm{DA}]_{\mathrm{p}}, \mathrm{Vmax}$, and $\mathrm{Km}$ have been previously reported. The $\mathrm{Km}$ and Vmax for DAT have been estimated using synaptosome preparations from different brain regions. Interestingly, the $\mathrm{Km}$ is about four times higher in the striatum than in the median eminence (Annunziato et al., 1980, 1981, 1984). Similarly, the Vmax is about five times smaller in the striatum than in the median eminence (Annunziato et al., 1980). Here we will analyze the striatal interface, where $\mathrm{Km}$ has been estimated in a range from 0.03 micromolar up to 2.3 micromolar (Coyle, 1969; Annunziato et al., 1980; Paton, 1980; Sarkar et al., 1983; Near et al., 1988; Horn, 1990; Jones et al., 1995; Zahniser et al., 1999; Wu et al., 2001), although values up to 8 micromolar have been reported (Stamford et al., 1984). Such a wide range can be explained by different experimental sets. For the actual simulation we used a value $\mathrm{Km}=0.22$ micromolar, which is within the range reported by most authors. Similarly, the Vmax of the DAT has different values according to the brain region ( $\mathrm{Wu}$ et al., 2001). We used a value of $V \max =3.8$ micromolar/s, as reported by Wu et al. (2001).

At the steady state $d[D A] / d t=0$.

As the concentration of DA in WKY rats has been evaluated equal to $[\mathrm{DA}]=5.17 \mathrm{nM}$ (Carboni et al., 2003) in the striatum, whereas the firing is $f=4.5 \mathrm{~Hz}$ (Ruskin et al., 2001), it is possible to calculate $[\mathrm{DA}]_{\mathrm{p}}=17 \mathrm{nM}$. This value is below the range of $89-250 \mathrm{nM}$ reported using cyclic voltammetry. This technique is based on microsensors of 15 micrometers diameter and takes record of more than one axonal varicosity that have a density of $10^{8}$ synapses $/ \mathrm{mm}^{3}$; (Pickel et al., 1981; Garris et al., 1994). It allows the determination of DA concentration released after the artificial stimulation of DA fibers (thus setting $f$ to a fixed value), thus making possible to evaluate $[D A]_{p}$ However, on the one hand, the artificial stimulation of neurons with an extensive arborization, such as DA and NE, leads to a failure of release at individual synapses $99 \%$ of the time (Cunnane \& Stjarne, 1984), thus preventing a direct comparison between the frequency of excitation and the natural firing frequency of DA neurons. On the other hand, synapses fire more asynchronously in the unstimulated animal than in the stimulated one, causing a more rapid dilution in the extrasynaptic space (Kawagoe et al., 1992; Garris et al., 1994). Moreover, $[D A]_{p}$ has been suggested to change in relation to VMAT2 expression, D2 receptor stimulation, DAT activity, and firing frequency (Garris et al., 1994; Pothos et al., 2000; Ingram et al., 2002; Wu et al., 2002). These effects might explain the difference in $[D A]_{p}$ calculated in our model or after artificial stimulation (such as in voltammetry studies).

As a matter of fact, the firing rate of DA neurons $(f)$ changes in vivo from pacemaker, to random, to burst modes (Schultz, 2002). During the burst mode, a transient rate exceeding $30 \mathrm{~Hz}$ (Wightman \& Robinson, 2002), a large, phasic increase of DA is evident, whereas the tonic DA release is due to random and pacemaker modes (Paladini et al., 2003). The firing rate is also regulated by the activation of D2 autoreceptors (Schmitz et al., 2003). Dopamine binds to D2 autoreceptors forming the complex DA.D2, a reaction that, at equilibrium, respects the Law of mass:

$$
[D A . D 2]_{e q}=B \max ^{*}[D A] /\left(K_{d}+[D A]\right)
$$

where $B \max =[D A]+[D 2]$ represents the total number of receptors, and $\mathrm{Kd}$ is the concentration of DA required to occupy $50 \%$ of the receptors. Estimates for $\mathrm{Bmax}$ and $\mathrm{Kd}$ in rat striatum are $B \max =0.5-2.3 \mathrm{pmol} \mathrm{mg}^{-1}$ protein or 100 micromolar (Matres et al., 1985; Boyson et al., 1986; Joyce \& Marshall, 1987; Richfield et al., 1989; Albert et al., 1990). Estimations for Kd are 7.4 to 43 nanomolar (Seeman et al., 1985; Richfield et al., 1989; Albert et al., 1990) in the high-affinity state, which comprises $74 \%$ of the binding sites 
(Richfield et al., 1989), and 4550 to 4300 nanomolar in the low affinity state (Seeman et al., 1985; Richfield et al., 1989).

The DA.D2 receptor complex has multiple effects, such as: (i) decreased amount of DA released after a spike (Garris et al., 1994), (ii) increased activity of the DAT (Cass \& Gerhard, 1994; Schmitz et al., 2001, 2002; Wu et al., 2002), (iii) regulation of potassium channels (Uchimura et al., 1986; Lacey et al., 1988), and voltage-dependent calcium channels (Cardozo \& Bean, 1995), which in turn hyperpolarize the cell membrane, thus decreasing the probability of DA release and the firing rate of DA neurons (Einhorn et al., 1988; Lacey et al., 1988; Mercuri et al., 1997; Ruskin et al., 2001; Ingram et al., 2002; Paladini et al., 2003). The first two effects are presynaptic and more evident at target sites (e.g. the neostriatum, accumbens, $\mathrm{PFc}$ ). The third one takes place in the nuclei of origin (VTA, SN) and is due to D2 autoreceptors on the soma and dendrites of DA cells (Carlsson, 1975; Starke, 2001). In this case, DA derives from axon collaterals, which form a feedback, or from the same dendrites (Falkenburger et al., 2001). Some have suggested that small doses of D2 agonist would act primarily on these autoreceptors, thus inhibiting the firing rate, whereas D2 receptors on target sites would be activated by higher doses of D2 agonists (Skirboll et al., 1979; Ruskin et al., 2001).

We restricted the analysis to the effects on the firing rate, as we were interested in low doses of MPH:

$$
\mathrm{d} f \mathrm{dt}=-f([\mathrm{DA} \cdot \mathrm{D} 2])
$$

Experimental data (Skirboll et al., 1979; Einhorn et al., 1988) would suggest, indeed, that the spontaneous firing rate decays linearly with the external concentration of DA. Therefore, the above formula can be empirically simplified with:

$$
\mathrm{d} f \mathrm{dt}=-\mathrm{k}^{*}[\mathrm{DA}]
$$

The firing rate of DA neurons is also regulated in vivo by a complex neuronal network comprising GABA, glutamate, NE, acetylcholine, serotonin, and nitric oxide influences (see e.g. (West \& Grace, 2000; Grillner, 2002)). For instance, inactivation of the ventral pallidum enhances DA release, resetting the steady state level to a new point (Floresco et al., 2003). These influences are not completely described from a quantitative perspective. By blocking the D2 autoreceptors (setting $\mathrm{k}=0$ ), however, it is possible to study $\mathrm{df} / \mathrm{dt}$, deriving empirically the sum of all these influences. After blockade of D2 autoreceptor the firing rate of DA neurons increases initially almost linearly, until a new steady state is reached (Einhorn et al., 1988; Ruskin et al., 2001).

We assumed that all these influences could be described using a single parameter, DF (Driving Force), which increases linearly the firing rate when D2 autoreceptors are blocked:

$$
\mathrm{d} f \mathrm{dt}=\mathrm{DF}
$$

Combining equations (8) and (9) we get:

$$
\mathrm{d} f \mathrm{dt}=\mathrm{DF} \cdot \mathrm{k} *[\mathrm{DA}]
$$

The appropriate value for DF can be empirically derived by studying the rate of change of DA neurons firing blocking D2 autoreceptors. In our model we set $D F=1.5$ spikes $/ \mathrm{s}^{2}$ (Ruskin et al., 2001). Moreover, the basal firing rate of DA neurons can be calculated from slice experiments, in which all the connections are cut, in the presence of a D2 inhibitor ( $D F=0, D A . D 2=0, f=$ const). Under these conditions, $f=1.2 \pm 0.2 \mathrm{~Hz}$ (Ingram et al., 2002). Without $D 2$ inhibition, in the presence of DA, the firing rate rapidly drops to $0.1 \pm 0.1 \mathrm{~Hz}$, as expected by Eq. (8). In vivo, where DAT, D2, and DF are present at the same time, the typical basal firing rate is about $5 \mathrm{~Hz}$ (Ruskin et al., 2001; Xu \& Shen, 2001).

The differential Eqs. (5) and (10) have been solved in the Matlab environment, based on an 
explicit Runge-Kutta (Forsythe et al., 1977) formula. The system reaches a steady state very rapidly. Because we were interested in the steady state responses after blockade of the DAT by MPH, we changed the parameter $\mathrm{Km}$ and calculated the new steady state for $f$ and [DA]. In, fact, to simulate the effects of methylphenidate injection, we considered the maximal concentration of methylphenidate in the brain and in the blood after i.p. injection using published data (Wargin et al., 1983; Aoyama et al., 1997; Huff 7 Davies, 2002; Swanson \& Volkow et al., 2002, 2003). The blood concentration of methylphenidate is approximately linear to the injection dose (expressed in $\mathrm{mg} / \mathrm{kg}$ body weight), although the ratio between dose and blood concentration is about 10 for an oral dose, but 1 for i.p injections. The brain concentration of methylphenidate has been considered here as approximately equal to the blood concentration, as suggested by data from Huff and Davies (2002).

The inhibition constant $(\mathrm{Ki})$ of methylphenidate has been reported to be $41.3 \pm 73.8 \mathrm{nM}$ (Aoyama et al., 1997). Methylphenidate has chemical and structural properties similar to those of cocaine
(Schweri et al., 2002), and, at least for its methylated derivative, has been reported to bind to the WIN site of DAT, increasing its $\mathrm{Km}$ but leaving the Vmax unchanged, acting in this way as a competitive inhibitor (Keener \& Sneyd, 1998; Schweri et al., 2002):

$$
\mathrm{Km}=0.22 *\left(1+\left([\mathrm{MPH}]_{\text {blood }} / \mathrm{Ki}\right)\right)
$$

We simulated the steady state concentration of DA following stepwise increases of methylphenidate $(0.1$ to $40 \mathrm{mg} / \mathrm{kg})$. The percent of firing rate and DA level were calculated and reported on semi log scale (Fig. 2). As shown in figure, the model reproduces the experimental data reported by (Ruskin et al., 2001). In fact, the blockade of the re-uptake increases extracellular DA, which acts on D2 autoreceptors, thus reducing DA neuron firing. methylphenidate has been also described to increase DA release in rats (Kalivas, 1989; Carboni et al., 2003) and humans as well (Seeman, 2002). This effect suggests that methylphenidate changes also the stimulation of DA neurons (DF), since, at the steady state, the level of DA is regulated by DF and $k$. In fact, DAT
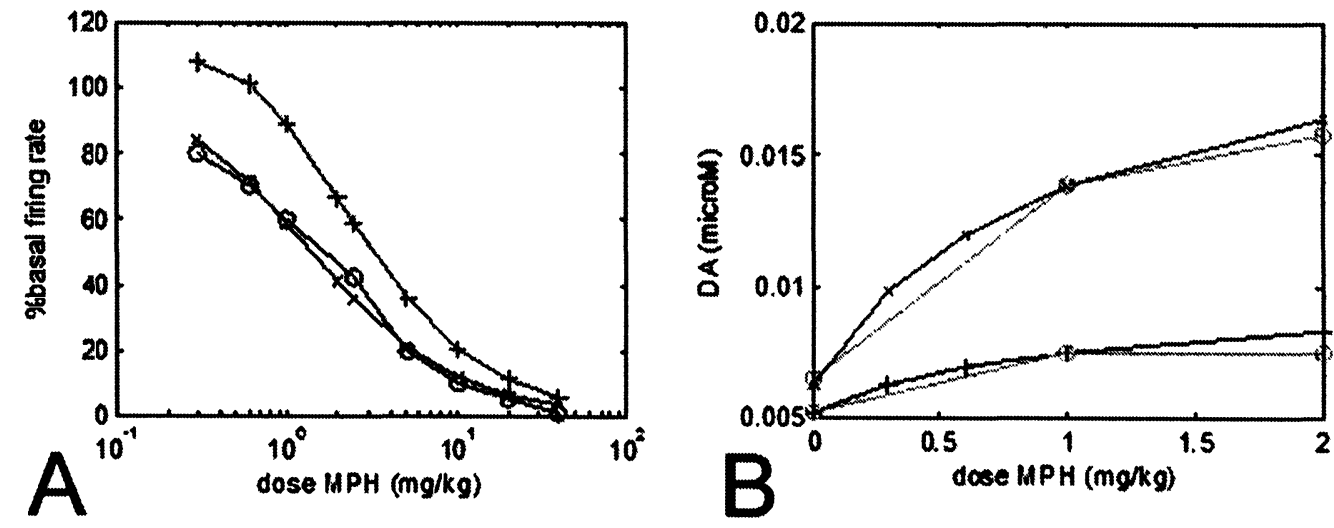

Fig. 2: Model of dopamine regulation; relationship between dose of methylphenidate (MPH) and firing frequency of dopamine neurons (A) or extracellular dopamine concentration (B). $\mathrm{O}$, experimental data. $\mathrm{X}$, simulated data for control rats (WKY). +, simulated data for SHR. 
knockout mice, which lack the molecular target of $\mathrm{MPH}$, still respond to this psychostimulant (Gainetdinov et al., 1999). It can be assumed that methylphenidate also increases DF. Data from literature (Carboni et al., 2003) allow to estimate such effect. The normal resting level of extracellular DA is approximately $4 \mathrm{nM}$ (Garris et al., 1994; Seeman \& Madras, 2002), and 5.7nM in WKY rats (Cárboni et al., 2003). This concentration can transiently rise of at least 60fold to about $250 \mathrm{nM}$ during a normal nerve impulse (phasic activity). The transiently elevated level of extracellular DA goes back to $4 \mathrm{nM}$ by diffusion, DAT activity, enzymatic degradation and autoxidation (Garris et al., 1994).

It should be noted that in SHR, the in vivo basal level of DA in the striatum is increased to $6.35 \mathrm{nM}$ versus $5.17 \mathrm{nM}$ in WKY rats (Carboni et al., 2003). This $20 \%$ difference can be modified by environmental factors, as suggested by Ferguson and Gough (2003). Moreover, aged, hypertensive animals might show reduced striatal DA (Linthorst et al., 1991). The enhanced DA outflow may result from increased DA release or decreased uptake or both. In fact, synaptosome preparations from SHR rats suggested a reduction in the uptake by $28 \%$ compared to WKY (Leo et al., 2003), although the number of DAT binding might be increased (Watanabe et al., 1997).

Because at the steady state $(\mathrm{df} / \mathrm{dt}=0)[\mathrm{DA}]=$ $\mathrm{DF} / \mathrm{k}$, the increase of [DA] might be due to a decreased effect of $\mathrm{D} 2$ receptors on the firing rate (k), as suggested by autoradiography studies (Sadile, 1999) and by lower responsivity of SHR to D2 blockers (van den Buuse et al., 1992).

Moreover, the induction of DA release by depolarization with $\mathrm{K}^{+}$or electrical stimulation leads to a greater increase of DA in WKY rats than in SHR (Russell et al., 2000; Carboni et al., 2003). This can be modeled by a decrease in $[D A]_{p}$ in SHR, as suggested by the previously observed reduction in TH levels (King et al., 2000; Leo et al., 2003; Masuo et al., 2004 - this issue). Thus, at the steady state $(\mathrm{dDA} / \mathrm{dt}=0)$, the firing rate of $\mathrm{DA}$ neurons is predicted to be higher in SHR than in WKY rats. Methylphenidate $\left(1 \mathrm{mg} \mathrm{kg}^{-1}\right)$ increases the steady state DA level to a greater extent in SHR than in WKY rats, suggesting a different response to methylphenidate in these animals. In fact, methylphenidate elevates the steady-state level of DA up to $7.5 \mathrm{nM}$ in WKY (150\%) and up to $13.97 \mathrm{nM}$ in SHR (220\%) (Carboni et al., 2003) (see also Fig 2). This tonic increase in DA produced by methylphenidate is negligible with respect to the concentrations during the burst activity that reaches the micromolar range. Recent evidence (see Wightman et al., 2002) demonstrated that discrete, phasic DA signals accompany rewarding or alerting stimuli. Therefore, the effects of low doses of methylphenidate on alert and attention are possibly due to a different mechanism. In fact, simulated and experimental data suggest that the firing rate is strongly decreased during the tonic and phasic discharge after methylphenidate treatment (Einhorn et al., 1988; Ruskin et al., 2001). Low doses of methylphenidate would decrease the firing rate in SHR to the level of WKY, whereas higher doses are predicted to decrease the firing rate well below the 4Hz of WKY (Ueno et al., 2002 2002; Yang et al., 2003). It is likely to hypothesize that the latter effect eventually impairs the responsivity of the system to salient novel stimuli.

Recently Volkow et al., 2002 (2002) suggested that individual responses to methylphenidate are due in part to individual differences in DA release, so that for an equivalent level of DAT blockade, methylphenidate would induce smaller DA changes in subjects with low DA than in those with high DA cell activity. Taken altogether, however, the data suggest that in a hyperDArgic system small doses of methylphenidate could actually have positive effects by reducing the firing rate of DA neurons, with small changes in the elevated extracellular DA.

As a matter of fact, the firing of DA neurons 
has behavioral relevance, whereas the amount of tonic DA release is of great importance for its neurotoxicity and locomotor activity. Consistently, high doses of methylphenidate increase locomotor activity (Drolet et al., 2002). Moreover, elevated resting levels of DA in SHR rats are associated to a segmental defect consisting of a change in D1, D3, and CAMK-II levels in a restricted segment of the anterior forebrain (Sadile, 1999). This change is likely to be due to the neurotoxic effects of DA in the rostral striatum. This defect could be reverted by subchronic treatment with methylphenidate or postnatal stimulation during the $5^{\text {th }}$ and $6^{\text {th }}$ week of postnatal life. The effect of methylphenidate was transient, however, as the modification reversed following drug withdrawal. Conversely, the effect of postnatal stimulation was permanent. These beneficial effects are consistent with decreased DA after postnatal handling (Ferguson \& Cada, 2003). Conversely, the longterm effects of methylphenidate are likely to involve changes in the DA machinery.(Porrino \& Lucignan, 1987; Andersen et al., 2002; Yang et al., 2003) (which are not included in our model) and await further investigation.

\section{ACKNOWLEDGMENTS}

We are grateful to Dr. Lars Schwabe for the modeling approach and to $\mathrm{Dr}$. Xiuxia $\mathrm{Du}$ for helpful comments. We are also grateful to Dr. Nick Foulkes for critical reading. This research was supported by a grant from MIUR-COFIN 2001/2002 and Ministry of Health-Special Funds.

\section{REFERENCES}

Adriani W, Caprioli A, Granstrem O, Carli M, Laviola G. 2003. The spontaneously hypertensive-rat as an animal model of ADHD: evidence for impulsive and non-impulsive subpopulations. Neurosci
Biobehav Rev 27: 639-651.

Albert PR, Neve KA, Bunzow JR, Civelli O. 1990. Coupling of a cloned rat dopamine-D2 receptor to inhibition of adenylyl cyclase and prolactin secretion. J Biol Chem 265: 2098-2104.

Andersen SL, Arvanitogiannis A, Pliakas AM, LeBlanc C, Carlezon WA, Jr. 2002. Altered responsiveness to cocaine in rats exposed to methylphenidate during development. Nat Neurosci 5: 13-14.

Annunziato L, Cerrito F, Raiteri M. 1981. Characteristics of dopamine release from isolated nerve endings of the tuberoinfundibular neurones. Neuropharmacology 20: 727-731.

Annunziato L, Di Renzo G, Amoroso S, Quattrone A. 1984. Release of endogenous dopamine from tuberoinfundibular neurons. Life Sci 35: 399-407.

Annunziato L, Leblanc P, Kordon C, Weiner RI. 1980. Differences in the kinetics of dopamine uptake in synaptosome preparations of the median eminence relative to other dopaminergically inervated brain regions. Neuroendocrinology 31 : 316-320.

Aoyama T, Yamamoto K, Kotaki H, Sawada Y, Iga T. 1997. Pharmacodynamic modeling for change of locomotor activity by methylphenidate in rats. Pharm Res 14: 1601-1606.

Aspide R, Fresiello A, De Filippis G, Gironi Carnevale UA, Sadile AG. 2000. Non selective attention in a rat model of hyperactivity and attention deficit: subchronic methylphenidate and nitric oxide synthesis inhibitor treatment. Neurosci Biobehav Rev 24: 59-71.

Aspide R, Gironi Carnevale UA, Sagvolden T, Sergeant JA, Sadile AG. 1996. Novelty-induced rearing duration as index of attention at low motivational levels in two animal models of ADHD in children. Proc IBNS, Cancun, Mexico 5: 65-65.

Boyson SJ, McGonigle P, Molinoff PB. 1986. Quantitative autoradiographic localization of the D1 and D2 subtypes of dopamine receptors in rat brain. J Neurosci 6: 3177-3188.

Carboni E, Silvagni A, Di Chiara G. 2004. Experimental investigations on dopamine transmission can provide clues on the therapeutic effect of amphetamine and methylphenidate in ADHD. Neural Plast 11: 73-92, this issue.

Carboni E, Silvagni A, Valentini V, Di Chiara G. 2003. Effect of amphetamine, cocaine and 
depolarization by high potassium on extracellular dopamine in the nucleus accumbens shell of SHR rats. An in vivo microdyalisis study. Neurosci Biobehav Rev 27: 653-659.

Cardozo DL, Bean BP. 1995. Voltage-dependent calcium channels in rat midbrain dopamine neurons: modulation by dopamine and $\mathrm{GABAB}$ receptors. J Neurophysiol 74: 1137-1148.

Carlson JH, Bergstrom DA, Walters JR. 1987. Stimulation of both D1 and D2 dopamine receptors appears necessary for full expression of postsynaptic effects of dopamine agonists: a neurophysiological study. Brain Res 400: 205218.

Carlsson A. 1975. Dopaminergic autoreceptors. In: Almgren O, Carlson A, Engel J, eds, Chemical Tools in Catecholamine Research. Amsterdam: North Holland Publishing Co; 219-225.

Cass WA, Gerhardt GA. 1994. Direct in vivo evidence that D2 dopamine receptors can modulate dopamine uptake. Neurosci Lett 176: 259-263.

Castellanos FX, Giedd NN, Marsh WL, Hamburger SD, Vaituzis AC, Dickstein DP, et al. 1996. Quantita-tive brain magnetic resonance imaging in attention-deficit hyperactivity disorder. Arch Gen Psychiatry 53: 607-616.

Comings DE. 2001. Clinical and molecular genetics of ADHD and Tourette syndrome. Two related poly-genic disorders. Ann N Y Acad Sci 931: 50 83.

Coyle JT, Snyder SH. 1969. Antiparkinsonian drugs: inhibition of dopamine uptake in the corpus striatum as a possible mechanism of action. Science 166: 899-901.

Cragg SJ, Nicholson C, Kume-Kick J, Tao L, Rice ME. 2001. Dopamine-mediated volume transmission in midbrain is regulated by distinct extracellular geometry and uptake. J Neurophysiol 85: 1761-1771.

Cunnane TC, Stjarne L. 1984. Transmitter secretion from individual varicosities of guinea-pig and mouse vas deferens: highly intermittent and monoquantal. Neuroscience 13: 1-20.

Davids E, Zhang K, Tarazi FI, Baldessarini RJ. $20 \hat{0} 3$. Animal models of attention-deficit hyperactivity disorder. Brain Res Brain Res Rev 42: 1-21.

Davies W, Isles AR, Wilkinson LS. 2001. Imprinted genes and mental dysfunction. Ann Med 33: 428436. de Jong W, Linthorst AC, Versteeg HG. 1995. The nigrostriatal dopamine system and the development of hypertension in the spontaneously hypertensive rat. Arch Mal Coeur Vaiss 88: 1193-1196.

Doare L, Puech AJ, Simon P. Dose related sequence of effects induced by the DA agonist 2-(N,Ndipropyl)-amino-5,6-dihydroxytetralin. J Pharmacol 1986. 17: 60-64.

Drolet G, Proulx K, Pearson D, Rochford J, Deschepper CF. 2002. Comparisons of behavioral and neurochemical characteristics between WKY, WKHA, and Wistar rat strains. Neuropsychopharmacology 27: 400-409.

Einhorn LC, Johansen PA, White FJ. 1988. Electrophysiological effects of cocaine in the mesoaccumbens dopamine system: studies in the ventral tegmental area. J Neurosci 8: 100-112.

Falkenburger BH, Barstow KL, Mintz IM. 2001. Dendrodendritic inhibition through reversal of dopamine transport. Science 293: 2465-2470.

Ferguson SA, Cada AM. 2003a. A longitudinal study of short- and long-term activity levels in male and female spontaneously hypertensive, WistarKyoto, and Sprague-Dawley rats. Behav Neurosci 117: 271-282.

Ferguson SA, Gough BJ, Cada AM. 2003b. In vivo basal and amphetamine-induced striatal dopamine and metabolite levels are similar in the spontaneously hypertensive, Wistar-Kyoto and Sprague-Dawley male rats. Physiol Behav 80: 109-114.

Floresco SB, West AR, Ash B, Moore H, Grace AA. 2003. Afferent modulation of dopamine neuron firing differentially regulates tonic and phasic dopamine transmission. Nat Neurosci 6: 968-973.

Forsythe G, Malcolm M, Moler C. 1977. In: Forsythe G, Malcolm M, Moler C, ed, Computer Methods for Mathematical Computations. Englewood Cliffs, New Jersey, USA: Prentice-Hall.

Fox GB, Pan JB, Esbenshade TA, Bennani YL, Black LA, et al. 2002. Effects of histamine $\mathrm{H}(3)$ receptor ligands GT-2331 and ciproxifan in a repeated acquisition avoidance response in the spontaneously hypertensive rat pup. Behav Brain Res 131: 151-161.

Fujita S, Okutsu H, Yamaguchi H, Nakamura S, Adachi K, Saigusa T, et al. 2003. Altered pre- and postsynaptic dopamine receptor functions in spontaneously hypertensive rat: an animal model 
of attention-deficit hyperactivity disorder. J Oral Sci 45: 75-83.

Fuller RW, Hemrick-Luecke SK, Wong DT, Pearson D, Threlkeld PG, Hynes MD, III. 1983. Altered behavioral response to a D2 agonist, LY141865, in spontaneously hypertensive rats exhibiting biochemical and endocrine responses similar to those in normotensive rats. J Pharmacol Exp Ther 227: 354-359.

Gainetdinov R, Wetsel W, Jones S, Levin E, Jaber M, Caron M. 1999. Role of serotonine in the paradoxical calming effect of psychostimulants on hyperactivity. Science 283: 397-401.

Garris PA, Christensen JR, Rebec GV, Wightman RM. 1997. Real-time measurement of electrically evoked extracellular dopamine in the striatum of freely moving rats. J Neurochem 68: 152-161.

Garris PA, Ciolkowski EL, Pastore P, Wightman RM. 1994. Efflux of dopamine from the synaptic cleft in the nucleus accumbens of the rat brain. $J$ Neurosci 14: 6084-6093.

Grillner P, Mercuri NB. 2002. Intrinsic membrane properties and synaptic inputs regulating the firing activity of the dopamine neurons. Behav Brain Res 130: 149-169.

Hellstrand K, Engel J. 1980. Locomotor activity and catecholamine receptor binding in adult normotensive and spontaneously hypertensive rats. J Neural Transm 48: 57-63.

Hendley ED, Ohlsson WG. 1991. Two new inbred rat strains derived from SHR: WKHA, hyperactive, and WKHT, hypertensive, rats. Am J Physiol 261: H583-H589.

Hendley ED, Wessel DJ, Atwater DG, Gellis J, Whitehorn D, Low WC. 1985. Age, sex and strain differences in activity and habituation in SHR and WKY rats. Physiol Behav 34: 379-383.

Horn AS. 1990. Dopamine uptake: a review of progress in the last decade. Progr Neurobiol 34: $387-400$.

Howes LG, Rowe PR, Summers RJ, Louis WJ. 1984. Age related changes of catecholamines and their metabolites in central nervous system regions of spontaneously hypertensive (SHR) and normotensive Wistar-Kyoto (WKY) rats. Clin Exp Hypertens A 6: 2263-2277.

Huff JK, Davies MI. 2002. Microdialysis monitoring of methylphenidate in blood and brain correlated with changes in dopamine and rat activity. J Pharm Biomed Anal 29: 767-777.
Inada T, Polk K, Jin C, Purser C, Hume A, Hoskins $B$, et al. 1992. Cocaine elevates striatal dopamine efflux in spontaneously hypertensive and WistarKyoto rats. Brain Res Bull 28: 227-231.

Ingram SL, Prasad BM, Amara SG. 2002. Dopamine transporter-mediated conductances increase excitability of midbrain dopamine neurons. Nat Neurosci 5: 971-978.

Jackson DM, Westlind-Danielsson A. 1994. Dopamine receptors: molecular biology, biochemistry and behavioural aspects. Pharmacol Ther 64: 291-370.

Jones SR, Garris PA, Kilts CD, Wightman RM. 1995. Comparison of dopamine uptake in the basolateral amygdaloid nucleus, caudate-putamen, and nucleus accumbens of the rat. J Neurochem 64 : 2581-2589.

Joyce JN, Marshall JF. 1987. Quantitative autoradiography of dopamine D2 sites in rat caudateputamen: localization to intrinsic neurons and not to neocortical afferents. Neuroscience 20: 773-795.

Kalivas PW, Bourdelais A, Abhold R, Abbott L. 1989. Somatodendritic release of endogenous dopamine: in vivo dialysis in the A10 dopamine region. Neurosci Lett 100: 215-220.

Kawagoe KT, Garris PA, Wiedemann DJ, Wightman RM. 1992. Regulation of transient dopamine concentration gradients in the microenvironment surrounding nerve terminals in the rat striatum. Neuroscience 51: 55-64.

Keener J, Sneyd J. 1998. In: Keener J, Sneyd J, eds, Matematical Physiology. New York, NY, USA: Springer-Verlag.

King JA, Barkley RA, Delville Y, Ferris CF. 2000. Early androgen treatment decreases cognitive function and catecholamine innervation in an animal model of ADHD. Behav Brain Res 107: $35-43$.

Kirouac GJ, Ganguly PK. 1993. Up-regulation of dopamine receptors in the brain of the spontaneously hypertensive rat: an autoradiographic analysis. Neuroscience 52: 135-141.

Kuczenski R, Segal D. 1989. Concomitant characterization of behavioral and striatal neurotransmitter response to amphetamine using in vivo microdialysis. J Neurosci 9: 2051-2065.

Lacey et al., MG, Mercuri NB, North RA. 1988. On the potassium conductance increase activated by GABAB and dopamine D2 receptors in rat substantia nigra neurones. J Physiol 401: 437-453.

Leo D, Sorrentino E, Volpicelli F, Eyman M, Greco D, 
Viggiano D, et al. 2003. Altered midbrain dopaminergic neurotransmission during development in an animal model of ADHD. Neurosci Biobehav Rev 27: 661-669.

Lim DK, Ito Y, Hoskins B, Rockhold RW, Ho IK. 1989. Comparative studies of muscarinic and dopamine receptors in three strains of rat. Eur $\mathrm{J}$ Pharmacol 165: 279-287.

Linthorst AC, de Jong W, de Boer T, Versteeg DH. 1993; Dopamine D1 and D2 receptors in the caudate nucleus of spontaneously hypertensive rats and normotensive Wistar-Kyoto rats. Brain Res 602: 119-125.

Linthorst AC, De Lang H, de Jong W, Versteeg DH. 1991. Effect of the dopamine D2 receptor agonist quinpirole on the in vivo release of dopamine in the caudate nucleus of hypertensive rats. Eur $\mathrm{J}$ Pharmacol 201: 125-133.

Linthorst AC, van Giersbergen PL, Gras M, Versteeg $\mathrm{DH}$, de Jong W. 1994. The nigrostriatal dopamine system: role in the development of hypertension in spontaneously hypertensive rats. Brain Res 639: 261-268.

Masuo Y, Ishido M, Morita M, Oka S. 2004. Effects of neonatal treatment with 6-hydroxydopamine and endocrine disruptors on motor activity and gene expression in the rat. Neural Plast 11: 5572 , this issue.

Matres M-P, Bouthenet ML, Sales N, Sokoloff P, Schwartz J-C. 1985. Widespread distribution of brain dopamine receptors evidenced with [125]iodosulpiride, a highly selectiveligand. Science 228: 752-755.

Mercuri NB, Scarponi M, Bonci A, Siniscalchi A, Bernardi G. 1997. Monoamine oxidase inhibition causes a long-term prolongation of the dopamineinduced responses in rat midbrain dopaminergic cells. J Neurosci 17: 2267-2272.

Missale C, Nash SR, Robinson SW, Jaber M, Caron MG. 1998. Dopamine receptors: from structure to function. Physiol Rev 78: 189-225.

Montague P, McClure SM, Baldwin PR, Phillips PEM, Budygin EA, Stuber GD, et al. 2004. Dynamic control of dopamine delivery in freely moving animals. J Neurosci 24: 1754-1759.

Nakamura K, Shirane M, Koshikawa N. 2001. Sitespecific activation of dopamine and serotonin transmission by aniracetam in the mesocorticolimbic pathway of rats. Brain Res 897: 82-92.

Near JA, Bigelow JC, Wightman RM. 1988.
Comparison of uptake of dopamine in rat striatal chopped tissue and synaptosomes. J Pharmacol Exp Ther 245: 921-927.

Okamoto K. 1969. Spontaneous hypertension in rats. Int Rev Exp Pathol 7: 227-270.

Paladini CA, Robinson S, Morikawa H, Williams JT, Palmiter RD. 2003. Dopamine controls the firing pattern of dopamine neurons via a network feedback mechanism. Proc Natl Acad Sci USA 100: 2866-2871.

Paton DM. 1980. Neuronal transport of noradrenaline and dopamine. Pharmacology 21: 85-92.

Pehek EA, Schechter MD, Yamamoto BK. 1990. Effects of cathinone and amphetamine on the neurochemistry of dopamine in vivo. Neuropharmacology 29: 1171-1176.

Pickel VM, Beckley SC, Joh TH, Reis DJ. 1981. Ultrastructural immunocytochemical localization of tyrosine hydroxylase in the neostriatum. Brain Res 225: 373-385.

Piercey MF, Hyslop DK, Hoffmann WE. 1996. Excitation of type II caudate neurons by systemic administration of dopamine agonists. Brain Res 706: 249-258.

Piercey MF, Hoffmann WE, Smith MW, Hyslop DK. 1996. Inhibition of dopamine neuron firing by pramipexole, a dopamine D3 receptor-preferring agonist: comparison to other dopamine receptor agonists. Eur J Pharmacol 312: 35-44.

Porrino LJ, Lucignani G. 1987. Different patterns of local brain energy metabolism associated with high and low doses of methylphenidate. Relevance to its action in hyperactive children. Biol Psychiatry 22: 126-138.

Pothos EN, Larsen KE, Krantz DE, Liu Y, Haycock JW, Setlik W, et al. 2000. Synaptic vesicle transporter expression regulates vesicle phenotype and quantal size. J Neurosci 20: 7297-7306.

Richfield EK, Penney JB, Young AB. 1989. Anatomical and affinity state comparisons between dopamine D1 and D2 receptors in the rat central nervous system. Neuroscience 30: 767777.

Ruskin DN, Bergstrom DA, Shenker A, Freeman LE, Baek D, Walters JR. 2001. Drugs used in the treatment of attention-deficit/hyperactivity disorder affect postsynaptic firing rate and oscillation without preferential dopamine autoreceptor action. Biol Psychiatry 49: 340-350.

Russell V, Allie S, Wiggins T. 2000. Increased 
noradrenergic activity in prefrontal cortex slices of an animal model for attention-deficit hyperactivity disorder-the spontaneously hypertensive rat. Behav Brain Res 117: 69-74.

Russell VA. 2003. In vitro glutamate-stimulated release of dopamine from nucleus accumbens core and shell of spontaneously hypertensive rats. Metab Brain Dis 18: 161-168.

Russell VA, de Villiers AS, Sagvolden T, Lamm MC, Taljaard JJ. 2000. Methylphenidate affects striatal dopamine differently in an animal model for attention-deficit/hyperactivity disorder-the spontaneously hypertensive rat. Brain Res Bull 53: 187-192.

Sadile AG. 1993. What can genetic models tell us about behavioral plasticity? Rev Neurosci 4: 287303.

Sadile AG. 1999. Multiple evidence of a segmental defect in the anterior forebrain of an animal model of attention-deficit hyperactivity disorder. Soc Neurosci Abstr 25.

Sadile AG. 2000. Multiple evidence of a segmental defect in the anterior forebrain of an animal model of hyperactivity and attention deficit. Neurosci Biobehav Rev 24: 161-169.

Sadile AG, Gironi Carnevale UA, Vitullo E, Cioffi LA, Welzl H, et al. 1988. Maze learning of the Naples High- and Low-Excitability rat lines. Adv Biosci 70: 177-180.

Sadile AG, Lamberti C, Siegfried B, Welzl H. 1993. Circadian activity, nociceptive thresholds, nigrostriatal and mesolimbic dopaminergic activity in the Naples High- and Low-Excitability rat lines. Behav Brain Res 55: 17-27.

Sagvolden T, Pettersen MB, Larsen MC. 1993. Spontaneously hypertensive rats (SHR) as a putative animal model of childhood hyperkinesis: SHR behavior compared to four other rat strains. Physiol Behav 54: 1047-1055.

Samani NJ, Swales JD, Jeffreys AJ, Morton DB, Naftilan AJ, Lindpaintner K, et al. 1989. DNA fingerprinting of spontaneously hyper-tensive and Wistar-Kyoto rats: implications for hypertension research. J Hypertens 7: 809-816.

Sarkar DK, Gottschall PE, Meites J, Horn A, Dow RC, Fink G, et al. 1983. Uptake and release of $[3 \mathrm{H}]$ dopamine by the median eminence: evidence for presynaptic dopaminergic receptors and for dopaminergic feedback inhibition. Neuroscience 10: 821-830.
Schmitz Y, Benoit-Marand M, Gonon F, Sulzer D. 2003. Presynaptic regulation of dopaminergic neurotransmission. J Neurochem 87: 273-289.

Schmitz Y, Lee CJ, Schmauss C, Gonon F, Sulzer D. 2001. Amphetamine distorts stimulation-dependent dopamine overflow: effects on D2 autoreceptors, transporters, and synaptic vesicle stores. J Neurosci 21: 5916-5924.

Schmitz Y, Schmauss C, Sulzer D. 2002. Altered dopamine release and uptake kinetics in mice lacking D2 receptors. J Neurosci 22: 8002-8009.

Schonfuss D, Reum T, Olshausen P, Fischer T, Morgenstern R. 2001. Modelling constant potential amperometry for investigations of dopaminergic neurotransmission kinetics in vivo. $J$ Neurosci Methods 112: 163-172.

Schultz W. 2002. Getting formal with dopamine and reward. Neuron 36: 241-263.

Schultz W, Apicella P, Scarnati E, Ljungberg T. 1992. Neuronal activity in monkey ventral striatum related to the expectation of reward. $J$ Neurosci 12: 4595-4610.

Schultz W, Dayan P, Montague P. 1997. A neural substrate of prediction and reward. Science 275: 1593-1599.

Schweri MM, Deutsch HM, Massey AT, Holtzman SG. 2002. Biochemical and behavioral characterization of novel methylphenidate analogs. J Pharmacol Exp Ther 301: 527-535.

Seeman P, Madras B. 2002. Methylphenidate elevates resting dopamine which lowers the impulsetriggered release of dopamine: a hypothesis. Behav Brain Res 130: 79-83.

Seeman P, Madras BK. 1998. Anti-hyperactivity medication: methylphenidate and amphetamine. Mol Psychiatry 3: 386-396.

Seeman P, Watanabe M, Grigoriadis D, Tedesco JL, George SR, Svensson U, et al. 1985. Dopamine D2 receptor binding sites for agonists. A tetrahedral model. Mol Pharmacol 28: 391-399.

Skirboll LR, Grace AA, Bunney BS. 1979. Dopamine auto- and postsynaptic receptors: electrophysiological evidence for differential sensitivity to dopamine agonists. Science 206: 80-82.

Solanto MV. 1998. Neuropsychopharmacological mechanisms of stimulant drug action in attentiondeficit hypractivity disorder: a review and integration. Behav Brain Res 94: 127-152.

Solanto MV. 2000. Clinical psychopharmacology of AD/HD: Implications for animal models. Neurosci 
Biobehav Rev 24: 27-30.

Stamford JA, Kruk ZL, Millar J, Wightman RM. 1984. Striatal dopamine uptake in the rat: in vivo analysis by fast cyclic voltammetry. Neurosci Lett 51: 133-138.

Starke K. 2001. Presynaptic autoreceptors in the third decade: focus on alpha2-adrenoceptors. J Neurochem 78: 685-693.

Strombom U. 1975. Effects of low doses of catecholamine receptor agonists on exploration in mice. $\mathrm{J}$ Neural Transm 37: 229-235.

Sutoo D, Akiyama K, Matsukura T, Nakamoto RK. 1993. Decrease of central dopamine level in the adult spontaneously hypertensive rats related to the calcium metabolism disorder. Brain Res Bull 30: 107-113.

Swanson JM, Volkow ND. 2003. Serum and brain concentrations of methylphenidate: implications for use and abuse. Neurosci Biobehav Rev 27: 615-621.

Tilson HA, Chamberlain JH, Gylys JA, Buyniski JP. 1977. Behavioral suppressant effects of clonidine in strains of normotensive and hypertensive rats. Eur J Pharmacol 43: 99-105.

Uchimura N, Higashi H, Nishi S. 1986. Hyperpolarizing and depolarizing actions of dopamine via $D-1$ and D-2 receptors on nucleus accumbens neurons. Brain Res 375: 368-372.

Ueno KI, Togashi H, Mori K, Matsumoto M, Ohashi S, Hoshino A, et al. 2002. Behavioural and pharmacological relevance of stroke-prone spontaneously hypertensive rats as an animal model of a developmental disorder. Behav Pharmacol 13: 1-13.

van den Buuse M, Jones CR, Wagner J. 1992. Brain dopamine D-2 receptor mechanisms in spontaneously hypertensive rats. Brain Res Bull 28: 289297.

van den Buuse $\mathrm{M}$, Linthorst $\mathrm{AC}$, Versteeg $\mathrm{DH}$, de Jong W. 1991. Role of brain dopamine systems in the development of hypertension in the spontaneously hypertensive rat. Clin Exp Hypertens A 13: 653-659.

van den Buuse $M$, Veldhuis $H D$, Versteeg $D H$, de Jong W. 1985. Behavioural factors contribute to the development of spontaneous hypertension in rats. J Hypertens Suppl 3: S101-S103.

van den Buuse M, Versteeg DH, de Jong W. 1986. Brain dopamine depletion by lesions in the substantia nigra attenuates the development of hypertension in the spontaneously hypertensive rat. Brain Res 368: 69-78.

Vaughan et al., CE, Van den BM, Roland BL. 1999. Brain dopamine D2 receptor mRNA levels are elevated in young spontaneously hypertensive rats. Neurosci Res 34: 199-205.

Venton BJ, Zhang H, Garris PA, Phillips PE, Sulzer D, Wightman RM. 2003. Real-time decoding of dopamine concentration changes in the caudateputamen during tonic and phasic firing. J Neurochem 87: 1284-1295.

Viggiano D, Grammatikopoulos G, Sadile AG. 2002a. A morphometric evidence for a hyperfunctioning mesolimbic system in an animal model of ADHD. Behav Brain Res 130: 181-189.

Viggiano D, Vallone D, Welzl H, Sadile AG. 2002b. The Naples High- and Low-Excitability rats: selective breeding, behavioral profile, morphometry, and molecular biology of the mesocortical dopamine system. Behav Genet 32: 315-333.

Viggiano D, Ruocco LA, Pignatelli M, Grammatikopoulos G, Sadile AG. 2003a. Prenatal elevation of endocannabinois corrects the unbalance between dopamine systems and reduces activity in the Naples High Excitability rats. Neurosci Biobehav Rev 27: 129-139.

Viggiano D, Vallone D, Ruocco LA, Sadile AG. 2003b. Behavioural, pharmacological, morphofunctional molecular studies reveal a hyperfunctioning mesocortical dopamine system in an animal model of attention deficit and hyperactivity disorder. Neurosci Biobehav Rev 27: 683-689.

Viggiano D, Sadile AG. 2000. Hypertrophic A10 dopamine neurons in a rat model of AttentionDeficit Hyperactivity Disorder (ADHD). Neuroreport 11:3677-3680.

Viggiano D, Ruocco LA, Arcieri S, Sadile AG. 2004. Involvement of norepinephrine in the control of activity and attentive processes in animal models of Attention Deificit Hyperactivity Disorder. Neural Plasticity 11: 135-150.

Volkow ND, Wang GJ, Fowler JS, Logan J, Franceschi D, Maynard L, et al. 2002. Relationship between blockade of dopamine transporters by oral methylphenidate and the increases in extracellular dopamine: therapeutic implications. Synapse 43 : 181-187.

Wargin W, Patrick K, Kilts C, Gualtieri CT, Ellington K, Mueller RA, et al. 1983. Pharmacokinetics of 
methylphenidate in man, rat and monkey. $\mathrm{J}$ Pharmacol Exp Ther 226: 382-386.

Watanabe Y, Fujita M, Ito Y, Okada T, Kusuoka H, et al. 1989. Dopamine D1 and D2 receptors in spontaneously hypertensive rat brain striatum. Can J Physiol Pharmacol 67: 1596-1597.

Watanabe Y, Fujita M, Ito Y, Okada T, Kusuoka H, Nishimura T. 1997. Brain dopamine transporter in spontaneously hypertensive rats. J Nucl Med 38: 470-474.

West AR, Grace AA. 2000. Striatal nitric oxide signaling regulates the neuronal activity of midbrain dopamine neurons in vivo. J Neurophysiol 83: 1796-1808.

Wightman RM, Amatore C, Engstrom RC, Hale PD, Kristensen EW, Kuhr WG, et al. 1988. Real-time characterization of dopamine overflow and uptake in the rat striatum. Neuroscience 25: 513-523.

Wightman RM, Robinson DL. 2002. Transient changes in mesolimbic dopamine and their association with 'reward'. J Neurochem 82: 721-735.

Wightman RM, Zimmerman JB. 1990. Control of dopamine extracellular concentration in rat striatum by impulse flow and uptake. Brain Res Brain Res Rev 15: 135-144.

Wu Q, Reith ME, Walker QD, Kuhn CM, Carroll FI, Garris PA. 2002. Concurrent autoreceptor-mediated control of dopamine release and uptake during neurotransmission: an in vivo voltammetric study. J Neurosci 22: 6272-6281.

Wu Q, Reith ME, Wightman RM, Kawagoe KT, Garris PA. 2001. Determination of release and uptake parameters from electrically evoked dopa- mine dynamics measured by real-time voltammetry. J Neurosci Methods 112: 119-133.

Wultz B, Sagvolden T, Moser EI, Moser MB. 1990. The spontaneously hypertensive rat as an animal model of attention-deficit hyperactivity disorder: effects of methylphenidate on exploratory behavior. Behav Neural Biol 53: 88-102.

$\mathrm{Xu} \mathrm{C}$, Shen RY. Amphetamine normalizes the electrical activity of dopamine neurons in the ventral tegmental area following prenatal ethanol exposure. J Pharmacol Exp Ther 2001. 297: 746752.

Yang PB, Amini B, Swann AC, Dafny N. 2003. Strain differences in the behavioral responses of male rats to chronically administered methylphenidate. Brain Res 971: 139-152.

Yousfi-Alaoui MA, Hospital S, Garcia-Sanz A, Badia A, Clos MV. 2001. Presynaptic modulation of $\mathrm{K}$ +-evoked [3H]dopamine release in striatal and frontal cortical synaptosomes of normotensive and spontaneous-hypertensive rats. Neurochem Res 26: 1271-1275.

Yu ZJ, Lim DK, Hoskins B, Rockhold RW, Ho IK. 1990. Effects of acute and subacute cocaine administration on the CNS dopaminergic system in Wistar-Kyoto and spontaneously hypertensive rats: I. Levels of dopamine and metabolites. Neurochem Res 15: 613-619.

Zahniser NR, Larson GA, Gerhardt GA. 1999. In vivo dopamine clearance rate in rat striatum: regulation by extracellular dopamine concentration and dopamine transporter inhibitors. J Pharmacol Exp Ther 289: 266-277. 

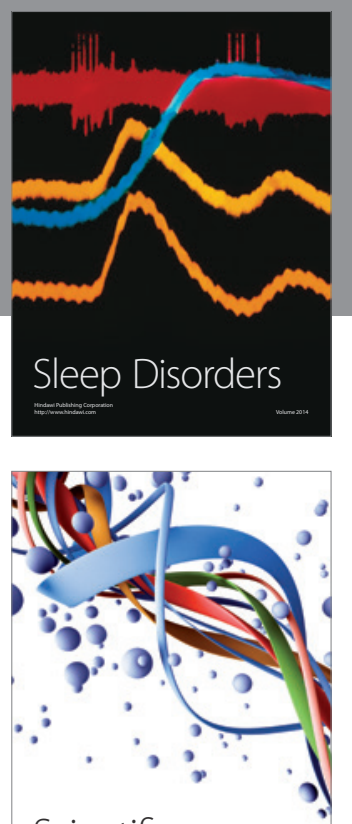

Scientifica
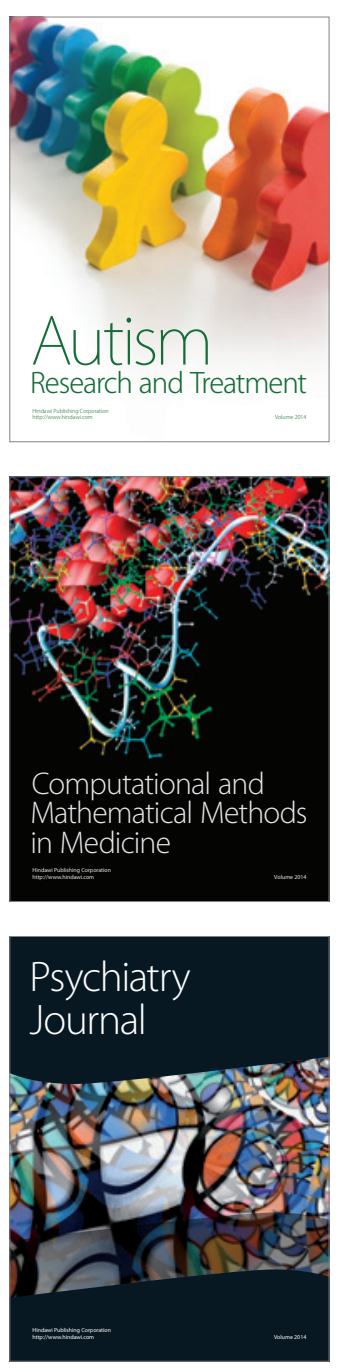
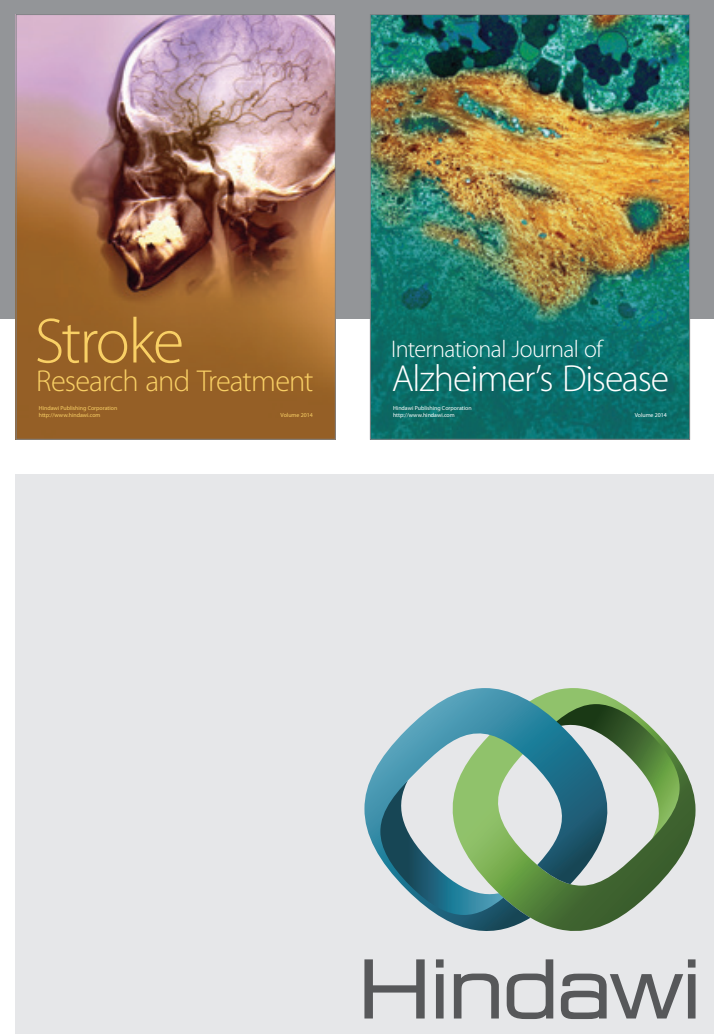

Submit your manuscripts at

http://www.hindawi.com
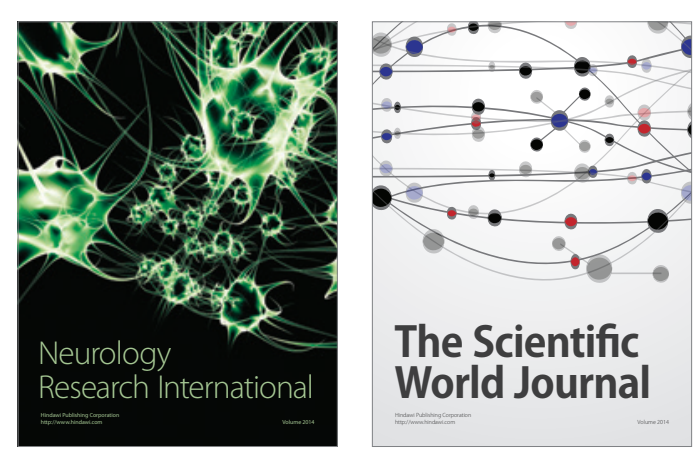

The Scientific World Journal

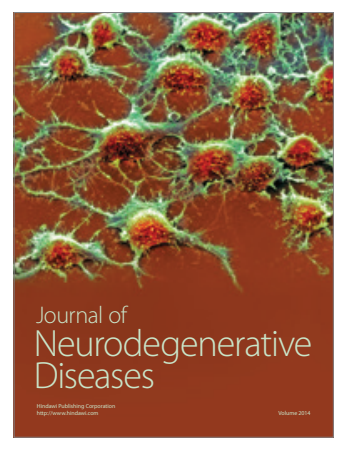

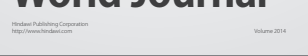

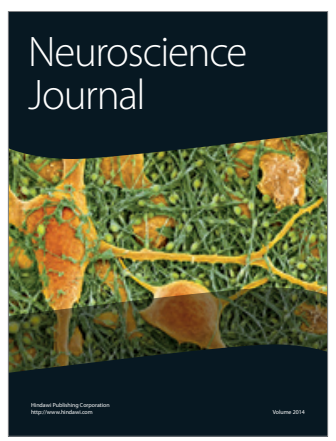

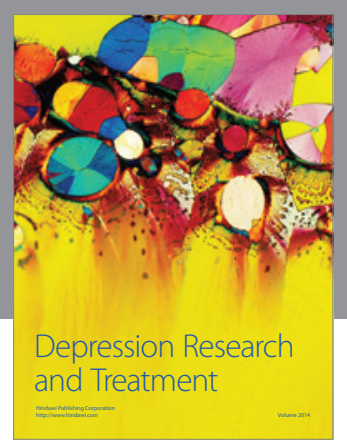
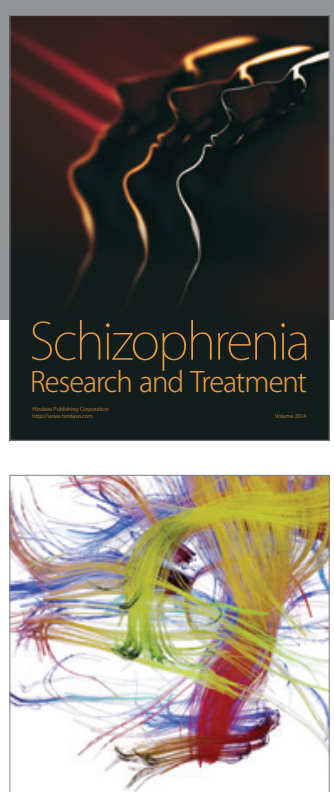

Brain Science

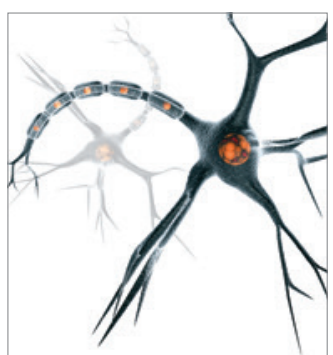

Neural Plasticity
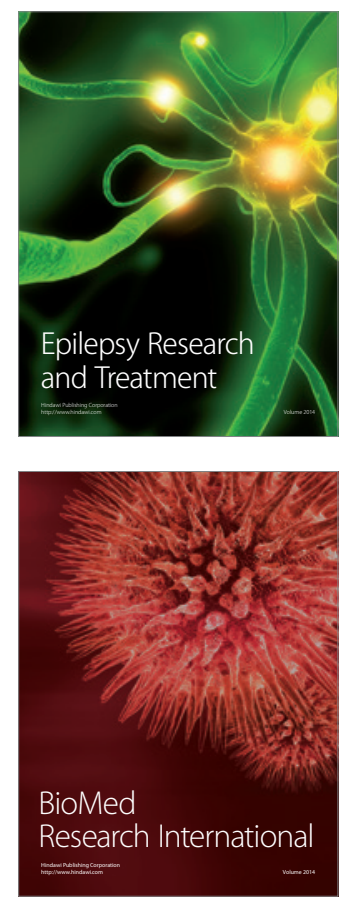

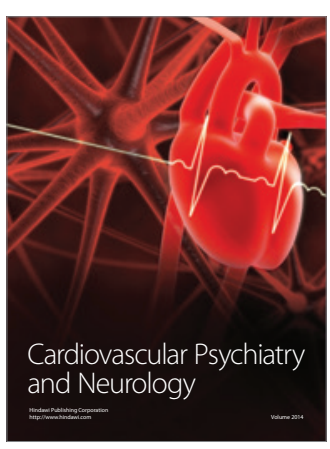

Parkinson's

Disease
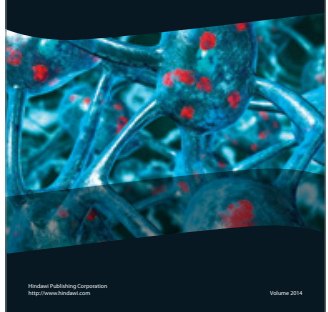